
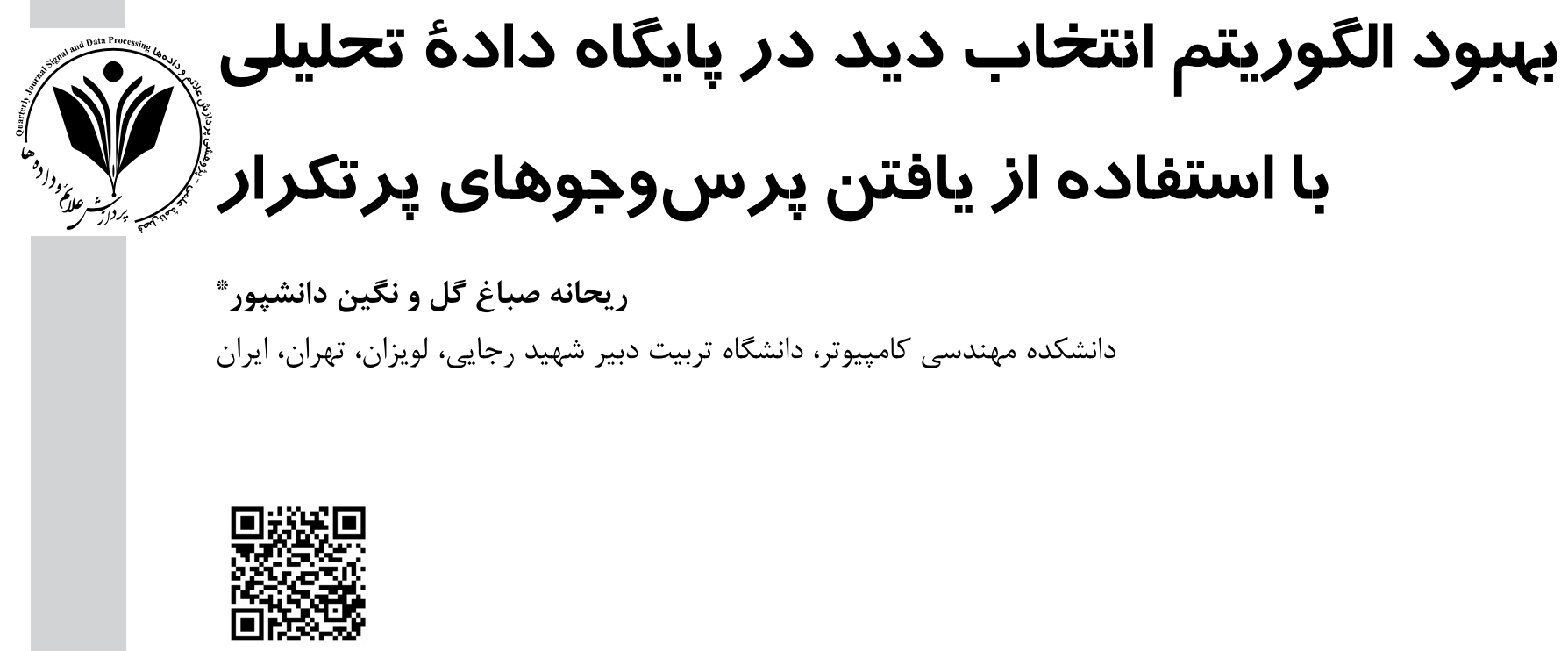

جكبر:

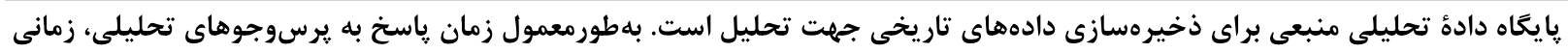

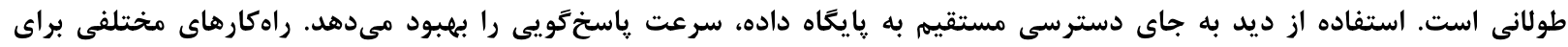

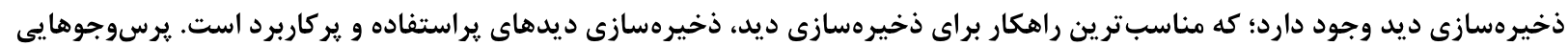

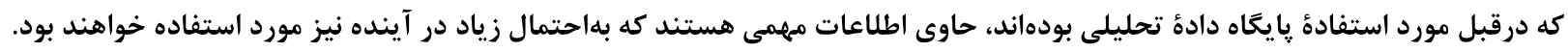

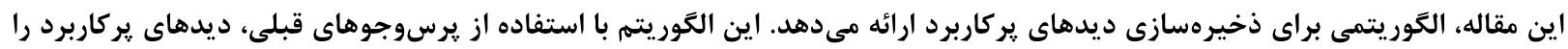

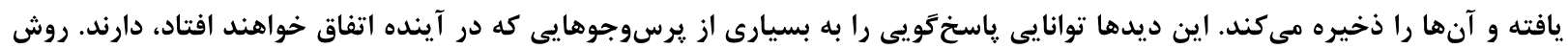

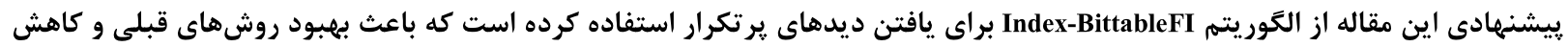

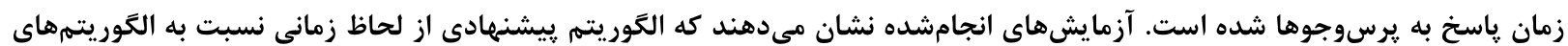

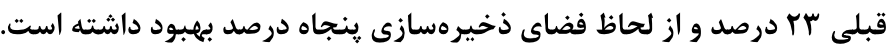

وازًَان كليدى: پايكاه دادهُ تحليلى، يرسوجوهاى يرتكرار، خوشهبندى، ذخيرهسازى ديد

\title{
An Improved View Selection Algorithm in Data Warehouses by Finding Frequent Queries
}

\section{Reyhaneh Sabbagh Gol and Negin Daneshpour"}

Faculty of Computer Engineering, Shahid Rajaee Teacher Training University, Tehran, Iran

\begin{abstract}
A data warehouse is a source for storing historical data to support decision making. Usually analytic queries take much time. To solve response time problem it should be materialized some views to answer all queries in minimum response time. There are many solutions for view selection problems. The most appropriate solution for view selection is materializing frequent queries. Previously posed queries on the data warehouse have profitable information. These queries probably will be used in the future. So, previous queries are clustered using clustering algorithms. Then frequent queries are found using data mining algorithms. Therefore optimal queries are found in each cluster. In the last stage optimal queries are merged to produce one (query) view for each cluster, and materializes this view. This paper proposes an algorithm for materializing frequent queries. The algorithm finds profitable views using previously posed queries on the data warehouse. These views can answer the most of the queriesbe ing posed in the future. This paper uses
\end{abstract}


Index-BittableFI algorithm for finding frequent views. Using this algorithm improves previous view selection algorithms and reduces the response time. The experiments show that the proposed algorithm has $\% 23$ improvement in response time and \%50 improvement in storage space.

\section{Keywords: Data warehouse, Frequent queries, View materialization, Clustering}

اجراى بالايى است و سرعت پاسخ به پرسو جوهاى تحليلى بسيار كم است. از طرفى ديخر با توجه به اين كه مهمترين عامل در الخوريتهمهاى انتخاب ديد، زمان است، بنابراين در اين مقاله، الكوريتمى يِيشنهاد شده است كه در زمان كمترى، به يرسوجوهاى تحليلى، ياسخ ميى دهد. الكوريتم انتخاب ديد ييشنهادشده در اين مقاله، با استفاده از الكوريتم Index-BittableFI [4] :برس و جوهاى يرتكرار را در هر خوشه بهدست مىآورد. الكوريتم ارائهشده در [3]،[2] و الكوريتهم ييشنهادى اين مقاله، يِيادهسازى شدهاند و

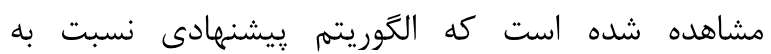
الكوريتمهاى بيانشده در منبع [3]،[2] بهبود داشته است. ساختار اين مقاله به شرح زير است: در بخش ب مقالات و الكوريتمهاى مرتبط با اين مقاله ارائه مىشود. در بخش ب الگوريتم انتخاب ديدى كه اين مقاله ارائه مىدهد بيان شده است. بخش Fٔ، به شرح پيادهسازى الكوريتم مى يردازد و بخش

$$
\text { ه به نتيجه گيرى مى بردازد. }
$$

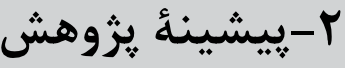

از جملئ نخستين الگوريتمهاى مطرحشده براى انتخاب ديد مى توان به الكوريتم حريصانه كه در سال 9V مطرح شده است، اشاره كرد [5]. الكوريتم حريصانه به اين صورت عمل مئ كند كه با استفاده از تابع سودى كه تعريف شده است، ديدهاى با باده سود بيشتر را انتخاب و با توجه به محدوديتهاى موجود از جمله فضاى نگهدارى آن ديدها را نخهدارى مى كند. البته اين الخوريتمها براى مسائل با ابعاد كمم مناسب هستند؛ ولى بـ براى مسائل با ابعاد بزرگ مناسب نيستند. برخى ديگر از روشها بر اساس گرافى كه رسم شده است تصميمگيرى مى كنند، برخى از اين گرافها عبارتند از

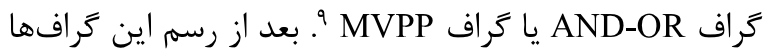
بر اساس تابع هزينهاى كه تعريف شده است، تصميمَيرى مىشود كه كدام ديدها انتخاب و ذخيره شوند[8]-[6]. اين

${ }^{6}$ Decision making

${ }^{7}$ Materialized View

${ }^{8}$ Join

${ }^{9}$ Multi-View Processing Plan

\section{doلمقام-1}

امروزه سازمانها و ادارات بزرت داراى حجم بسيار بالايى از دادهها هستند. اين دادهها در يايخاه دادههاى مختلفى ذخيره شدهاند. براى دسترسى به اين دادهها دو روش وجود دارد: روش تنبل ' و روش مشتاق ب در روش نخست دادهها بلوسيلة

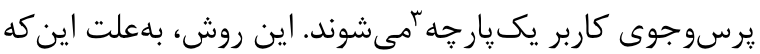
دادهها يس از اجراى ڤيرسوجوى كاربر يكيارجه مىشوند، داراى تأخير زيادى است و درنتيجه، روش مناسبى نيست. روش دوم از يايگاه داده تحليلى استفاده مى كند. در اين روش

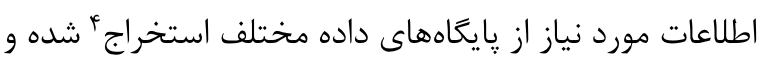

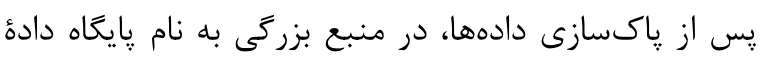

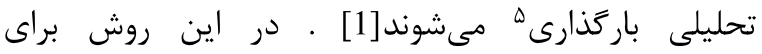

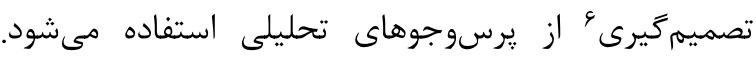

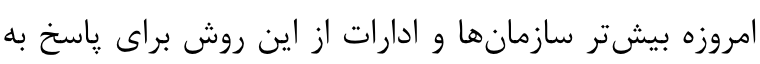
"يرسوجوهاى تحليلى تحليل קايگاه داده تحليلى بهمنظور كاهش زمان

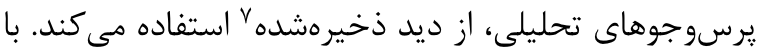
توجه به محدوديت فضاى ذخيرهسازى، و نيز زمان زياد باروزنتهداشتن ديدها، نمىتوان تمام ديدهاى ممكن رهن ذخيرهكرد؛ بنابراين بايد از بين تمامى ديدهاى ممكن، تنها

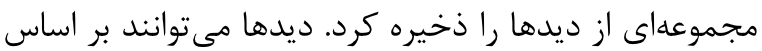

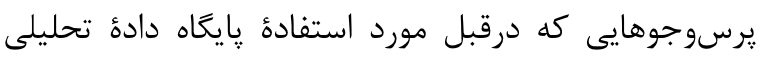

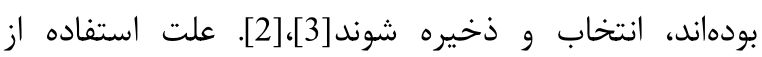
يرسوجوهاى قبلى، اين است كه بهاحتمال زياد در آينده

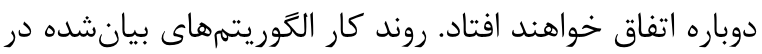
[3]،[2] به اين صورت است كه ابتدا يرسوجوهاى قبلى خوشهبندى مىشوند؛ سيس در هر خوشه پرسوجوهاى

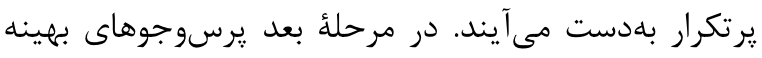
انتخاب مىشوند و درنهايت ترسوجوهاى بهينه در هر خوشه ييوند^ مىشوند. اين الگوريته بهعلت اينكه براى يافتن يرسوجوهاى يرتكرار در هر خوشه از الكوريتمهاى مقدماتى همجون Apriori و DIC استفاده كرده است، داراى زمان

\footnotetext{
${ }^{1}$ lazy

2 eager

3 integrate

${ }^{4}$ extraction

${ }^{5}$ load
} 
برخى از الكوريتمها، بهبوديافته الگوريتهم حريصانه

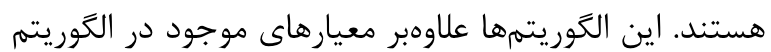
حريصانه، بر اساس اندازهُ يرسوجو، فر كانس تكرار يرسوجوها

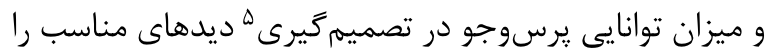

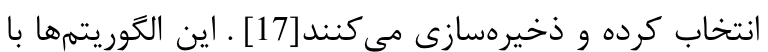
توجه به اين كه از شبكهاى از كعب ها استفاده مى كنند، براى مسائل با ابعاد كوجك مناسب هستند.

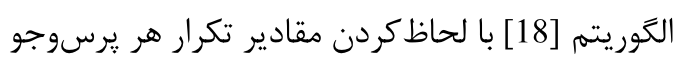
و استفاده از فرمول سود جديد توانسته است بهبودى نسبت به الگوريتم حريصانه حاصل كند. اين الگوريتم در ابتدا شبكة

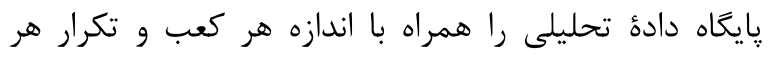
يرسوجو مى گيرد؛ سيس با استفاده از فرمول سود هر ديد، ديدهاى با سود بيشتر را بلهورت حريصانه انتخاب مى كند. اين الكوريتم هزينه نظمهدارى ديدهاى ذخيرهشده را در نظر

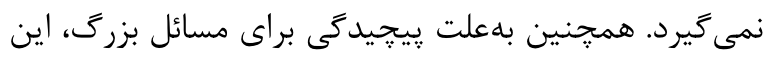

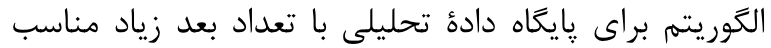

الكوريته [19] همانند الخوريتم حريصانه ديدهايى با بهترين سود را براى ذخيرهسازى انتخاب مى كند؛ با اين تفاوت

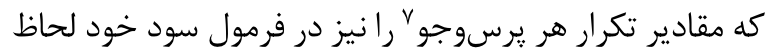
كرده است. اين الخوريتم هزينه نتمهدارى ديدهاى ذخيرهشده يره

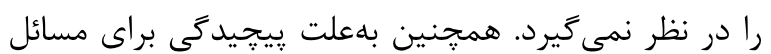
بزرگ، اين الكوريتم براى پايگاه داده تحليلى با تعداد بعد زياد

مناسب نيست.

الكوريتهم [20] داراى جندين بخش است. در اين الكوريتم ابتدا يرس و جوها بر اساس معيار شباهت و الكوريتم خوشهبندى سلسلهمراتبى، دستهبندى مىشوند. در مرحلة بعد، يس از اجراى جندين زير برنامئ ديدهاى منتخب براى

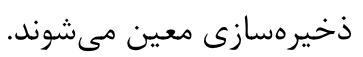
الكوريتم بيانشده در [21] با استفاده از جفت معيرى زنبور عسل ديدهاى مناسب را انتخاب و ذخيره مى كند. اين

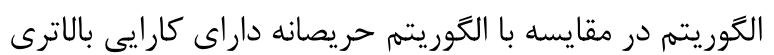

الكوريتهم بيانشده در [22] با استفاده از روشهاى دادهاوى يرس و جوهاى يرتكرار را مىيابد. در اين الگوريتم

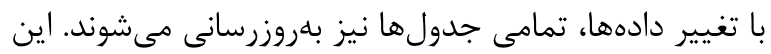
الكوريتم نسبت به الكوريتم حريصانه بهتر عمل مى كند.

${ }^{5}$ Decision making

${ }^{6}$ Lattice of cuboids

${ }^{7}$ Query Frequency
الخوريتمها با توجه به اين كه بايد گرافهاى مذكور رسم شوند،

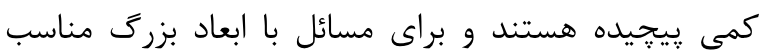
نيستند. برخى ديخر از الكوريتمها تأكيد زيادى روى تابع هزينه دارند[9] . اين روشها تابع سود يا هزينهاى تعريف كرده و ديدهايى با بيشترين سود و كمترين هزينه را انتخاب و ورون ذخيرهسازى مى كنند. از جمله عواملى كه در [9] مطرح شده است، عبارتند از: فركانس تكرار هر يرسوجو، زمان اجراى هر يرسوجو، تعداد ييوندها و مجتمعهاى' موجود در هر

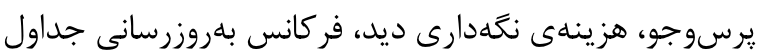
يايه، تعداد درجها، تعداد تغييرات و تعداد حذفها. با استفاده از روش بيانشده در [10]،كراف بدون دور مستقيمץ' مربوط به هر ديد رسم شده و و يس از يافتن كوتاهترين مسير، ديدهاى با بيشترين سود انتخاب و ذخيره مىشوند. در اين گراف يالها، ديدها مىباشند. البته اين الكوريتم براى مسائل با ابعاد كم مناسب و براى مسائل با ابعاد

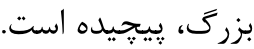

الكوريتم ارائهشده در [11] :يرسوجوى بعدى را ييشبينى كرده و بر اساس اين ييشبينى ديدهاى مورد نياز

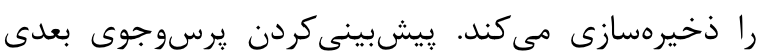
باعث مىشود، ديد مورد نياز براى آن يرسوجو، بهدرستى

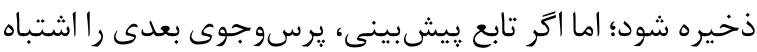

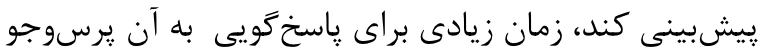
صرف خواهد شد. برخى ديكر از الكوريتمها از مدلهاى رياضى استفاده

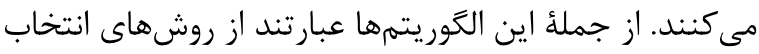

ديد با استفاده از مسئلة ارضاى محدوديتها؟ [14]-[12].

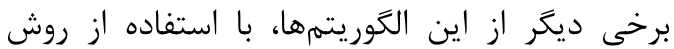
برنامهنويسى صحيح " مسئله را مدل كرده و با استفاده از

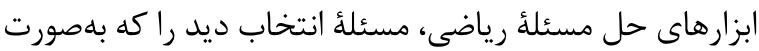
فرمول درآمده است، حلكرده و ديدهاى بهينه را انتخاب و ذخيرهسازى مى كنند [16]،[15]. اين الكوريتمها با توجه به اين كه مسئله را با استفاده از معادلات رياضى حل ميى كنند، جزء قدرتمندترين روشهاى حل مسائل هستند. اما با توجه

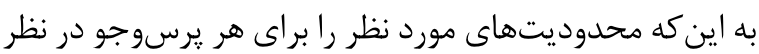

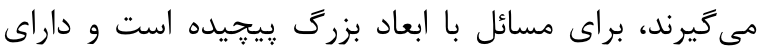
زمان اجراى بالايى خواهند بود.

\footnotetext{
${ }^{1}$ Aggregate

${ }^{2} \mathrm{DAG}$

${ }^{3}$ Constraint Satisfaction Problem

${ }^{4}$ integer programming
} 
حاوى اطلاعات مفيدى هستند كه بهاحتمال زياد در آينده نيز

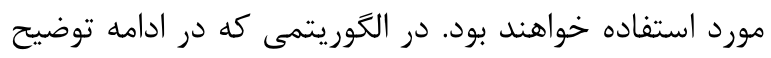
داده مىشود، روش يافتن يرسوجوهاى يرتكرار در روش

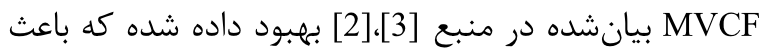

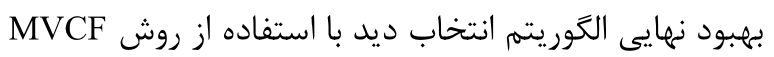

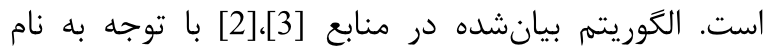
نويسند كان، الكوريتم الكَوريتم ييشنهادى در اين مقاله، الكوريتم SRTTU-2015 ناميده شده است. الكَوريتم ييشنهادى در ادامه توضيح داده

$$
\text { مىشود. }
$$

ابتدا يرسوجوهاى قبلى با استفاده از روش روش

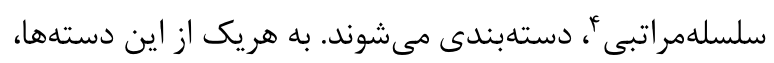

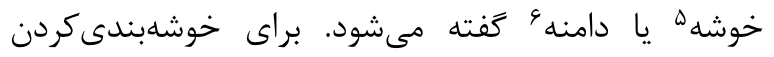

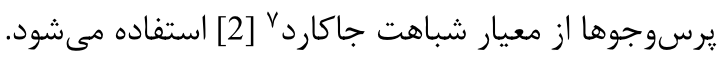

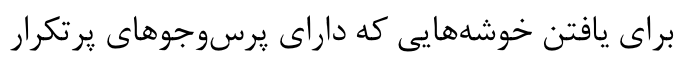

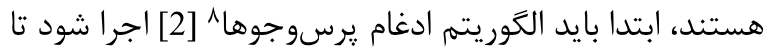

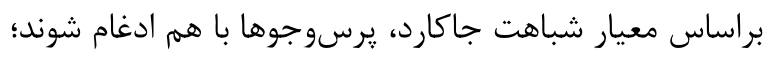

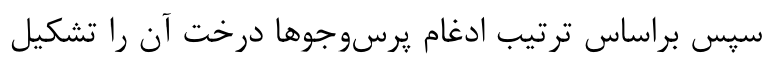
داده و خوشهها از روى درخت يافته شوند.

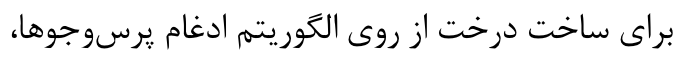

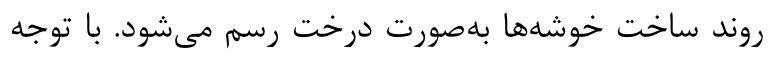

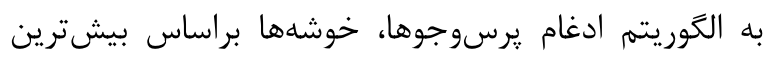

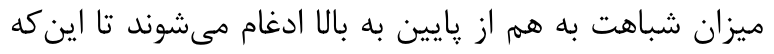

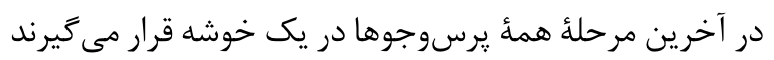

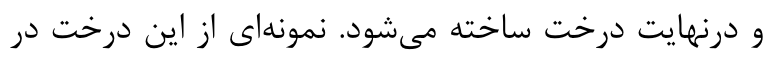

شكا ، (1) آمده است.

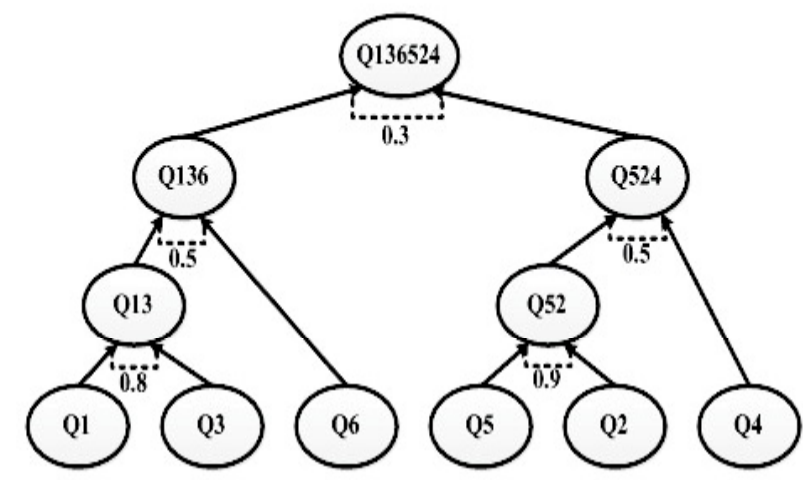

(شكل-1): درخت ساختهشده از روى الكوريتهم ادغام پيرسوجوها : (Figure-1): The tree made from merging queries' algorithm

\footnotetext{
${ }^{5}$ cluster

${ }^{6}$ domain, area, subject area

${ }^{7}$ Jaccard's coefficient

${ }^{8}$ Query Merger
}

الكوريتم معرفىشده در [23] تعدادى ديد نماينده' انتخاب مى كند؛ سيس عمليات حذف و اضافهكردن ديدها انجام مىشود؛ به اين صورت كه ديدهايى كه هزينه بالايى دارند، حذف شده و ديدهايى كه هزينهُ كمترى دارند اضافه مىشوند. درصورتى كه اين الگوريتم ديدهاى نماينده را به درستى انتخاب نكند، زمان ياسخ الگوريتم بسيار بالا خواهد

در برخى ديخر از روشها با استفاده از الخوريتمهاى بود. خوشهبندى و دادهكاوى، ديدهاى مناسب انتخاب مىشوند [26]-[24]،[3]،؛[2]. در اين الخوريتمها از ؛رسوجوهاى قبلى استفاده مىشود؛ علت اين امر، اين است كه بهاحتمال زياد در آينده نيز، اين يرسوجوها اتفاق خواهند افتاد. اين الگوريتمها

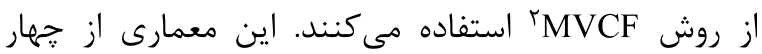
مرحله تشكيل شده است:

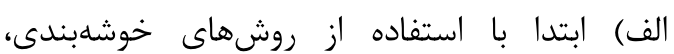

$$
\text { يرسوجوهاى قبلى خوشلبندى مىشوند. }
$$

ب) سيس با استفاده از روشهاى داده كاوى براى يافتن

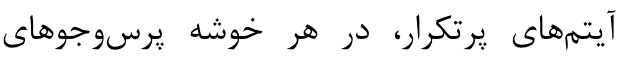

$$
\text { يرتكرار يافته مىشوند. }
$$

ج) سيس در هر خوشه، يرسوجوهاى بهينه انتخاب

$$
\text { مىشوند. }
$$

د) در اين مرحله، در هر خوشه يرسوجوهاى بهينه ادغام مىشوند تا بهازاى هر خوشه، يك ديد ديد

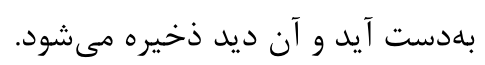

در [3]،؛[2] از الكوريتمهاى پايه مانند الخوريتم Apriori و DIC براى يافتن آيتمهاى يرتكرار در هر خوشه استفاده

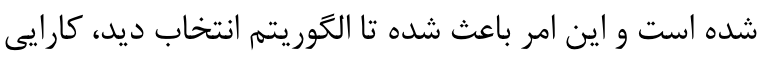
مناسبى نداشته باشد. بنابراين در اين مقاله از الگوريتم جديدترى براى ييادهسازى مراحل روش MVCF استفاده شده

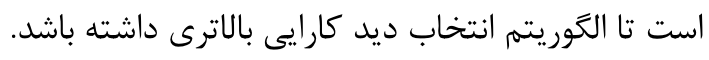

\section{r-الََوريتم انتخاب ديد يِيشنهادى}

در اين بخش الثوريتم ارائهشده در اين مقاله براى انتخاب ديد توصيف مىشود. اين الكوريتم از روش MVCF كه در بخش كارهاى مرتبط توضيح داده شده است، استفاده مى كند. در اين الكوريتهم از يرسوجوهايى كه درقبل مورد استفاده يايگًاه داده تحليلى بودهاند، استفاده شده است؛ زيرا اين يرسوجوها

\footnotetext{
${ }^{1}$ Candidate

${ }^{2}$ Materialized Views Construction Framework

${ }^{3}$ Dynamic Itemset Counting

${ }^{4}$ Hierarchical clustering
} 
به عبارت ديخر آرائ انديسى، يك آرايه با اندازه

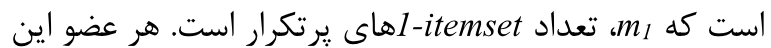

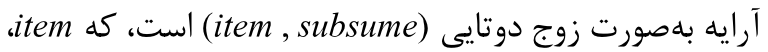
1-itemset است و subsume در فرمول (r) توصيف شده است. subsume $($ item $)=\{j \in I \mid$ item $\prec j \wedge g($ item $) \subseteq g(j)\}$ كه subsume(item) به اين معنى است كه اگر

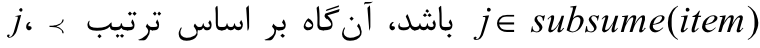
بعد از item قرار دارد. براى قيداكردن آيتمهاى يرتكرار، ابتدا

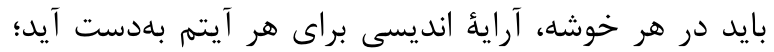
سيس با دردستداشتن آرائً انديسى تمام آيتمها، با استفاده از الكوريتم Index-BittableFI آيتمهاى يرتكرار در هر خوشه به دست آورده شوند. در قسمت (الف) الكوريتم ساختن آرائ انديسى توضيح داده شده است و در قسمت (ب) الكوريتم Index-BittableFI الكوريتمهاى بيانشده در قسمتهاى الف و ب بر يايهى منبع [4] است و در اين مقاله براى اين مسأله بازنويسى شده است.

\section{الف) الكوريتهم ساختن آرايةٌ انديسى:}

ابتدا الخوريتم ساختن آرائٔ انديسى مورد بررسى قرارمى گيردي. اين الكَوريتم در شكل (r) بيان شده است.

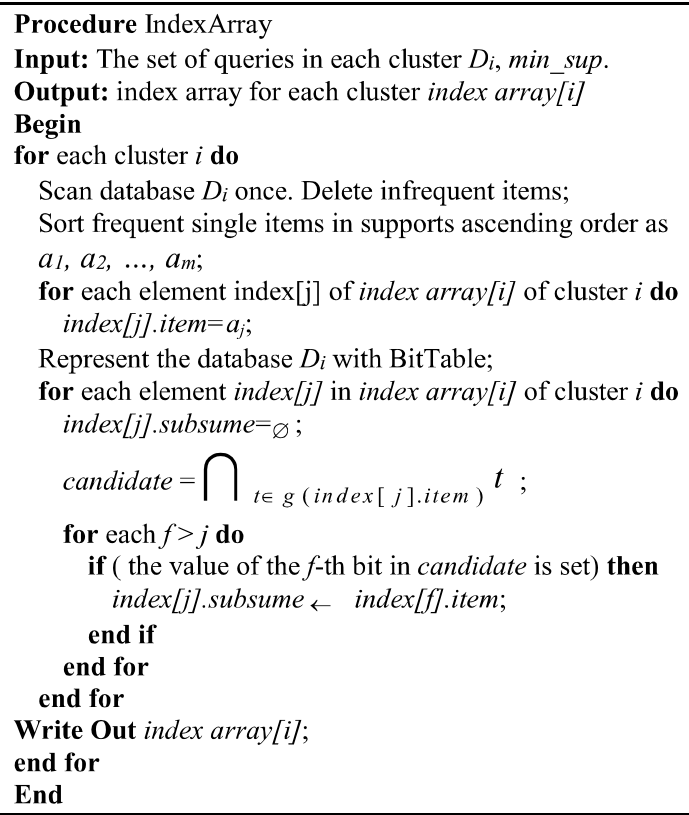

for each element index[j] of index array $[i]$ of cluster $i$ do index $[j] . i t e m=a_{j}$;

Represent the database $D_{i}$ with BitTable;

for each element index [j] in index array $[i]$ of cluster $i$ do index $[j]$.subsume $=\varnothing$;

candidate $=\bigcap_{t \in g(\text { index }[j] . \text { item })} t$;

for each $f>j$ do

if ( the value of the $f$-th bit in candidate is set) then index [j].subsume $\leftarrow$ index[f].item;

\section{end if}

end for

end for

Write Out index array $[i]$;

end for

End

$$
\begin{gathered}
\text { (شكل -r): الكوريتم ايجاد آرايهى انديسى براى الكوريتم } \\
\text { SRTTU-2015 }
\end{gathered}
$$

(Figure-2): Producing Index Array for SRTTU2015 algorithm

\footnotetext{
3 itemset
}

${ }^{4}$ Index array
يس از ساخت درخت، گرههاى درخت از بالا به يايين

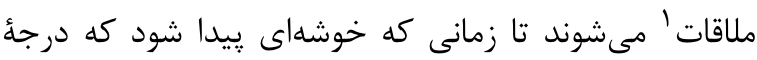

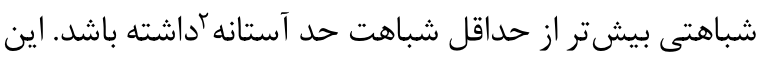
خوشهها نشاندهندة دامنهها خواهند بود. بلعنوان مثال در

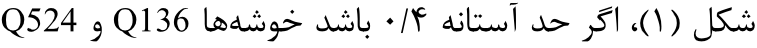
خواهند بود. توجه شود كه Q13 به اين معنى است كه اين

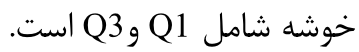
يس از يافتن خوشهها، بايد يرسوجوهاى يرتكرار در

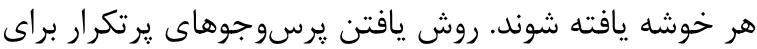

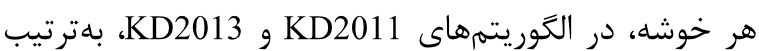
روش Apriori و DIC و است؛ الكوريتههاى Apriori الكوريتمهايى قديمى هستند و سبب مىشوند كه در زمان اجراى بالايى به يرسوجوهاى تحليلى ياسخ داده شود. از طرفى ديكر مهمترين عامل در الكوريتههاى انتخاب ديد، زمان اجرا است؛ بنابراين در الكَوريتم پِيشنهادى اين مقاله، از الكوريته Index-BittableFI [4] براى بهعبود زمان اجرا استفاده شده است. اين الكَوريتم براى يرسوجوهاى هر خوشه بررسى آنى مىشود تا يرسوجوهاى يرتكرار در هر خوشه بهدست آيند.

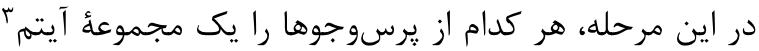
مىنامند. يك مجموعه آيتم كه داراى $k$ تا آيتم است،

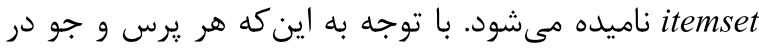

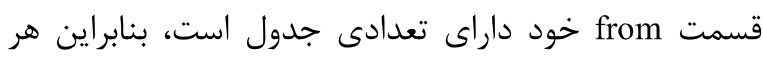
كدام از اين جداول، يك آيتم ناميده مىشود. نشاندهنده تعداد يرسوجوهايى است كه شامل آيتم آين هستند. اكر sup $(X)>$ min_sup باشد، آنغاه X يك يك آيتم يرتكرار

$$
\text { ناميده مىشود. }
$$

در الكوريتم Index-BittableFI، براى كاهش فضاى جستجو، آرائ انديسى ث تعريف مىشود. فرمول (1) تعريف رياضى آرائً انديسى است.

$$
g(\mathrm{X})=\{\mathrm{t} \in \mathrm{D} \mid \forall \mathrm{i} \in \mathrm{X}, \mathrm{i} \in \mathrm{t}\}
$$

كه در آن X، آيتمى است كه آرايةٔ انديسى آن يافته

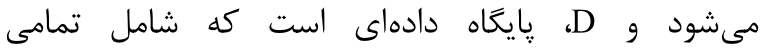
يرسوجوهاى هر خوشه است و t، مجموعهاى از آيتمهايى است كه هر يرسوجو شامل مىشود. اين آيتمها فيلدهاى مورد استفاده براى هر يرسوجو هستند.

\footnotetext{
${ }^{1}$ visit

${ }^{2}$ Minimum threshold
} 
ظرفيت كوله يشتى، يرسوجوها را در آن مىتوان قرارداد [26].

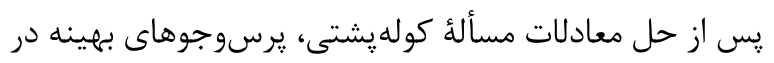

$$
\text { هر خوشه بهدست مى آيد. }
$$

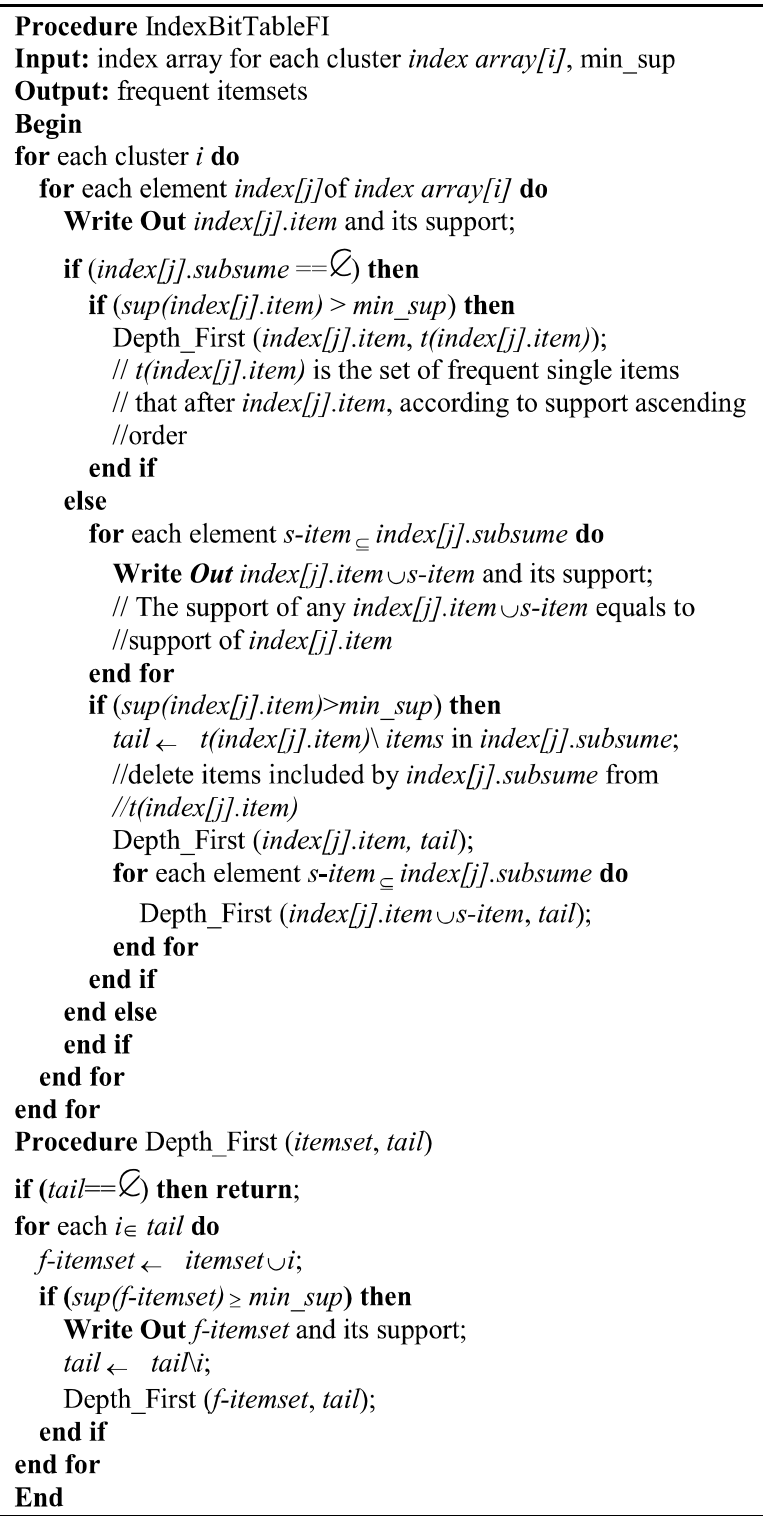

\section{(شكل-"r): الكَوريتم Index-BitTableFI براى الكَوريتم ييشنهادى}

(Figure-3): Index-BitTableFI algorithm that is needed for SRTTU-2015 proposed algorithm

بهعنوان مثال نمونهاى از معادلات در رابطة (ب) بيان

Maximise $13 Q_{1}+15 Q_{7}+28 Q_{16}+35 Q_{17}+32 Q_{20}$

subject to

$120 Q_{1}+250 Q_{7}+430 Q_{16}+310 Q_{17}+360 Q_{20} \leq 1000$

and

$Q_{i} s=0$ or 1 where $i=1,7,16,17,20$

${ }^{3}$ Optimal Queries
در ابتدا يايعاه داده مربوط به هر خوشه يعنى i

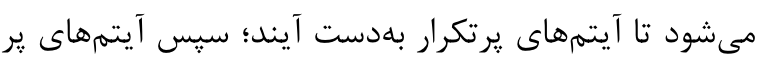

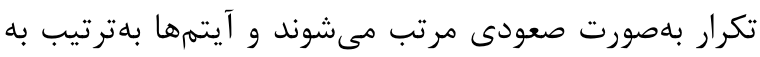

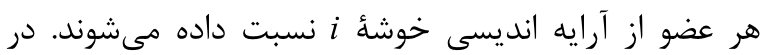

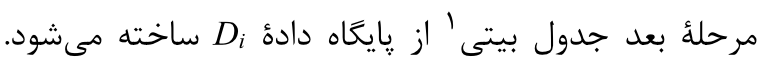
نحوه ساخت اين جدول به اين صورت است كه اتر يرسوجوى

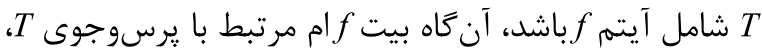

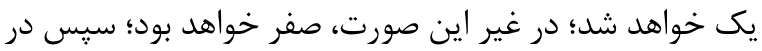
آخرين حلقه، آرائ انديسى توليد مئ دشود. ابتدا تمام يرسوجوهايى كه شامل index[j].item مىشوند، اشتراك گرفته مىشوند؛ سيس تمام آيتمهايى كه داراى انديس بالاترى نسبت به ز هستند، در index[j].subsume قرارمى درنهايت بهعنوان خروجى براى هر خوشه، يك آراية انديسى له

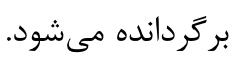

ب) الكوريتم Index-BitTableFI: اين الكوريتهم با استفاده از آرائٔ انديسى توليدشده در هر خوشه، آيتمهاى يرتكرار را ييدا مى كند. اين الكوريتم در شكل

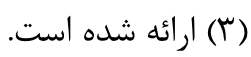

در ابتدا آيتمها و support آنها نوشته مىشود. در آر مرحلة بعد subsume مربوط به هرآيتم بررسى مىشود. در

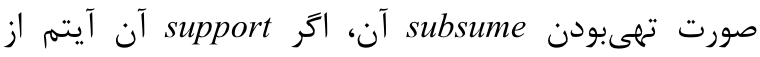
min_sup بيشتر باشد، آنغاه تابع نخستعمق گ اجرا مىشود. حال اگر subsume آن غيرتهى باشد، تمام زيرمجموعههاى

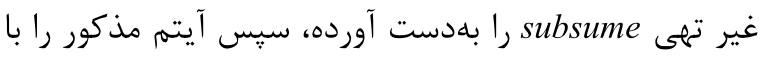
هر كدام از زيرمجموعهها ادغام مى كنيم. در اين حالت هر كدام از مجموعههاى بهدستآمده يك مجموعه آيتم ڤيرتكرار هستند كه support آنها همان support آيتم مذكور است. در اينجا نيز، اگر support آيتم مذكور بيشتر از min_sup باشد، تابع نخستعمق صدازده مىشود؛ سيس آيتم مورد نظر با تمام زيرمجموعههاى غير تهى ادغام شده و براى هر كدام تابع

$$
\text { نخستعمق صدازده مىشود. }
$$

يس از بهدستآوردن يرسوجوهاى ڤيرتكرار در هر هر

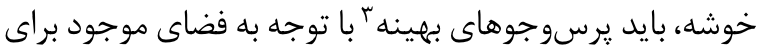
هر خوشه در هر خوشه بهدست آيند. فرض مىشود فضايى كه مىتواند براى ذخيرهسازى ديدهاى هر خوشه استفاده شود، فضاى كولهيشتى باشد؛ در اين صورت نمى نوان

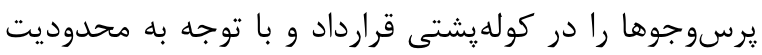

\footnotetext{
${ }^{1}$ BitTable

2 depth-first
} 
مىشوند، اين معيار تعداد سطرهاى ديدهاى ذخيرهشده را نشان ميدهد. r. زمان كل: اين زمان مجموع دو مدت زمان است: اولى مدت زمانى است كه الگوريتم انتخاب ديد اجرا مىشود؛ و دومى مدت زمانى است كه يرسوجوهاى آزمايش پاسخ داده مىشوند. r. زمان آزمايش: اين زمان، مدتزمان پاسخ به پرسوجوهاى آزمايش است.

در اين آزمايشها براى بلهستآوردن مقدار معيار مربوطه، ينجبار آزمايشها تكرار شده و ميانگين عددى ينج عدد حاصله، در نمودارهاى اين بخش ترسيم شده است. تنها پارامتر موجود در اين مسأله، يارامتر حد آستانه يوشش ז است. براى بهدست آوردن بهترين مقدار يارامتر حد آستانه يوشش آزمايشهاى مختلفى انجام شده است. در اين آزمايشها تعداد يرسوجوهاى ورودى و آزمايش، برابر ينجاه است. شكل (ع) نمودار تغييرات زمان كل در برابر تغييرات حد آستانه يوشش را نشان مىدهد. در اين نمودار محور افقى، مقدار حد آستانه يوشش و محور عمودى مقدار زمان كل است. همانطوركه در شكل (9) مشاهده مىشود بهترين مقدار براى حد آستانه يوشش، \&/ • است. بنابراين همانطوركه در بخشץ توضيح داده شد، با استفاده از اين يارامتر، خوشهها مشخص مىشوند.

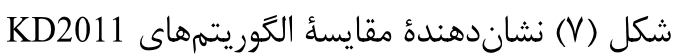
و KRTTU-2015 و بر اساس معيار شماره ( ) است. در اين نمودار محور افقى نشاندهنده تعداد يرسوجوها و محور عمودى نشاندهنده تعداد ركوردهاى ديدهاى ذخيرهشدهُ نهايى است.

با توجه به نمودار رسمشده در شكل (V) مشخص مىشود كه تعداد سطرهاى ديدهاى ذخيرهشده توسط الكوريتم ي يشنهمادىSRTTU-2015 هميشه كمتر از تعداد سطرهاى بلهدست آمده توسط الگوريتمهاى KD2011 و KD2013 است. اين بدين معناست كه الكوريتم ريشنههادى نياز به فضاى ذخيرهسازى كمترى دارد؛ ولى الكوريتمهاى KD2011 و KD2013 به فضاى ذخيرهسازى بيشترى احتياج دارند. اين مقايسه نشان مىدهد كه الكوريتم ييشنهادى SRTTU-2015 از لحاظ فضاى ذخيرهسازى بهتر است.

${ }^{3}$ Support threshold
يس از بلهستآ وردن برسوجوهاى بهينه در هر خوشه، بايد اين يرسوجوها ادغام شوند تا بهازاى هر خوشه، يك ديد ذخيره شود. هدف از اين مرحله اين است كه براى هر دامنه، يك يرسوجوى بهينه، ذخيره شود. در اين مرحله جداول مربوط به هر يرسوجو در هر خوشه، Natural Outer Join مىشوند. درنهايت براى هر دامنه يك ديد بهدست مى آيد و ورئ آن ديد ذخيره مىشود [3]. شكل (f) الكوريتم قييشنهادى را بلهصورت روندنما نشان مى دهد. روندنماى شكل (Y) مراحل كار الخوريتم پيشنههادى

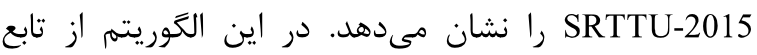
نخستعمق استفاده شده است كه اين تابع در روندنماى شكل

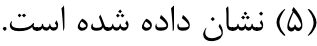

\section{F}

براى ريادهسازى الگوريتهمهاى KD2011، K2013

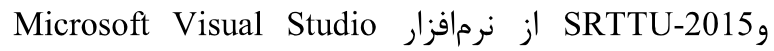
استفاده شده است. يايعاه داده مورداستفاده اين مقاله، Microsoft SQL Server دادههاى اين يايگًاه داده، بهصورت داده تصادفى توسط نرمافزار Microsoft Visual Studio توليد شده است. با توجه يه يهوه به اينكه دادهها بهصورت تصادفى توليد شدهاند، يس در آزمايشهاى صورت كرفته نتايج حاصل به يك نوع یايياه داده خاص حساس نيست. سامانٔ مورد استفاده براى ييادهسازى الكوريتمها داراى 4GB RAM و 2.2GHz يايگاه داده تحليلى مورد استفاده اين آزمايشها، داراى ده

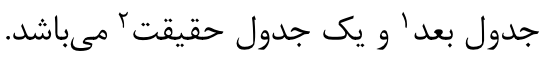

براى مقايسٔ الگوريتمهاى وSRTTU-2015، آزمايشهاى متعددى صورت كرفته است.

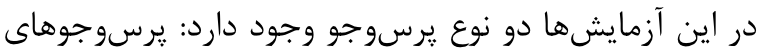
ورودى الگوريته و يرسوجوهاى آزمايش. پيرسوجوهاى

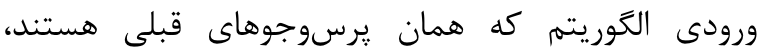
بهصورت دادههاى تصادفى توليد مىشوند؛ پيس از اجراى

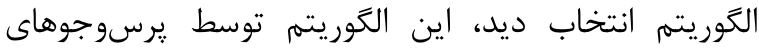

$$
\text { آزمايش مورد آزمايش قرار مى كيرد. }
$$

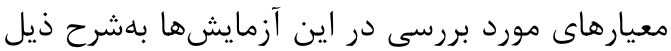

هستند:

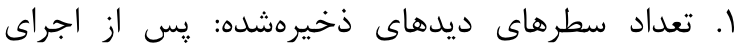

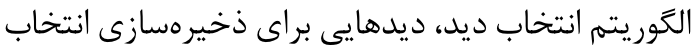

\footnotetext{
${ }^{1}$ Dimension

${ }^{2}$ Fact
} 


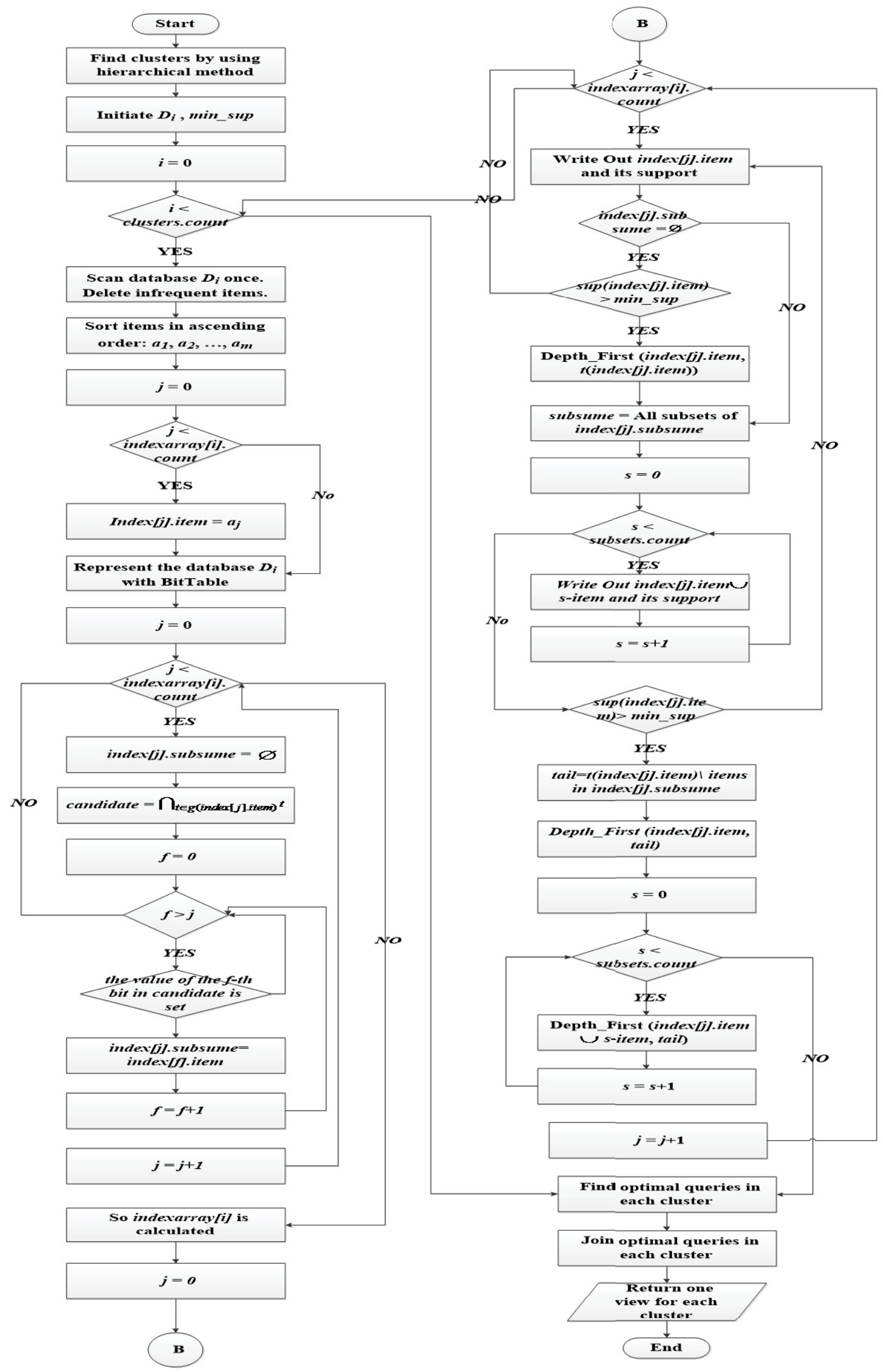

(شكل - F) : نمودار جعبهاى العوريتم SRTTU-2015

(Figure-4): Flowchart for SRTTU-2015 algorithm 


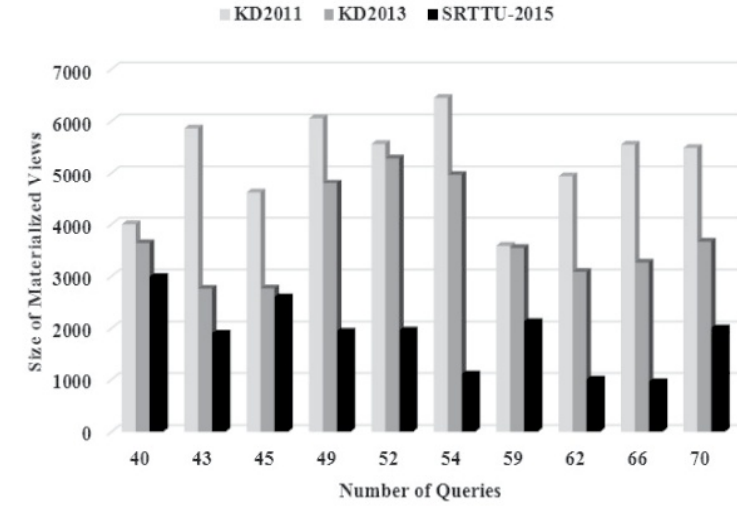

(شكل-V-): مقايسةٔ تعداد سطرهاى ديدهاى ذخيرهشده با افزايش

تعداد يرسوجوها

(Figure-7): Size of materialized views vs. number of queries

شكل (^) مقايسُٔ الكَريتهماى KD2011 و KD2013

و SRTTU-2015 بر اساس معيار شمارٔ (ז) است. محور افقى

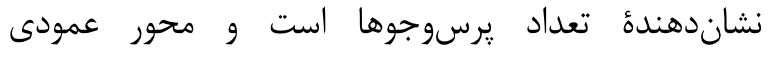

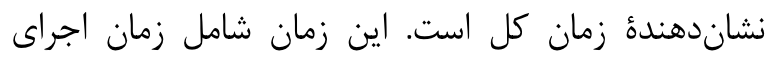

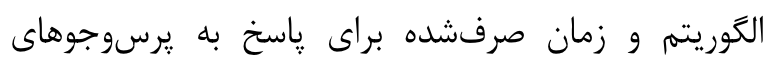
آزمايش است.

نمودار رسمشده در شكل (^) نشان مىدهد كه زمان

كل الكوريتم پيشنههادى SRTTU-2015 هميشه كمتر از زمان

كل الكوريتمهاى KD2011 و KD2013 است. با توجه به

اهميت زمان، هر الكوريتم انتخاب ديدى كه در زمان كمترى به يرسوجوهاى آزمايش پاسخ دهد، الكوريتم انتخاب ديد مناسبترى خواهد بود. با توجه به نمودار رسمشده در شكل

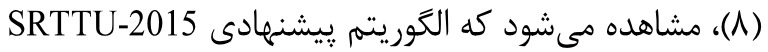
داراى زمان ياسخ كمترى بوده است.

KD2011 $=$ KD2013 -SRTTU-2015

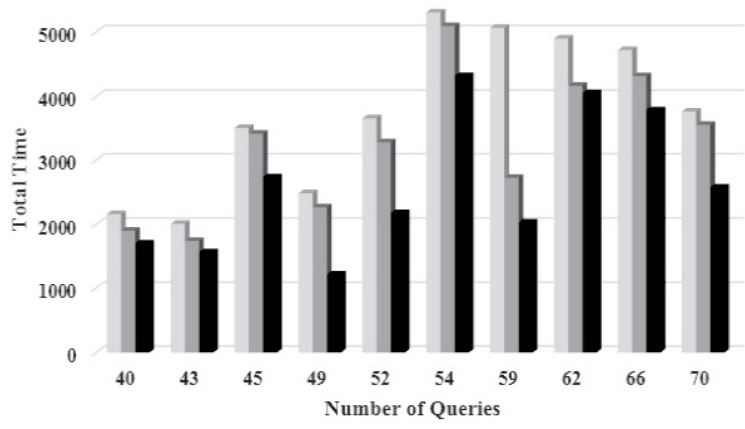

(شكل-A): مقايسهٔ زمان كل با افزايش تعداد يرسوجوها

(Figure-8): Total time vs. number of queris

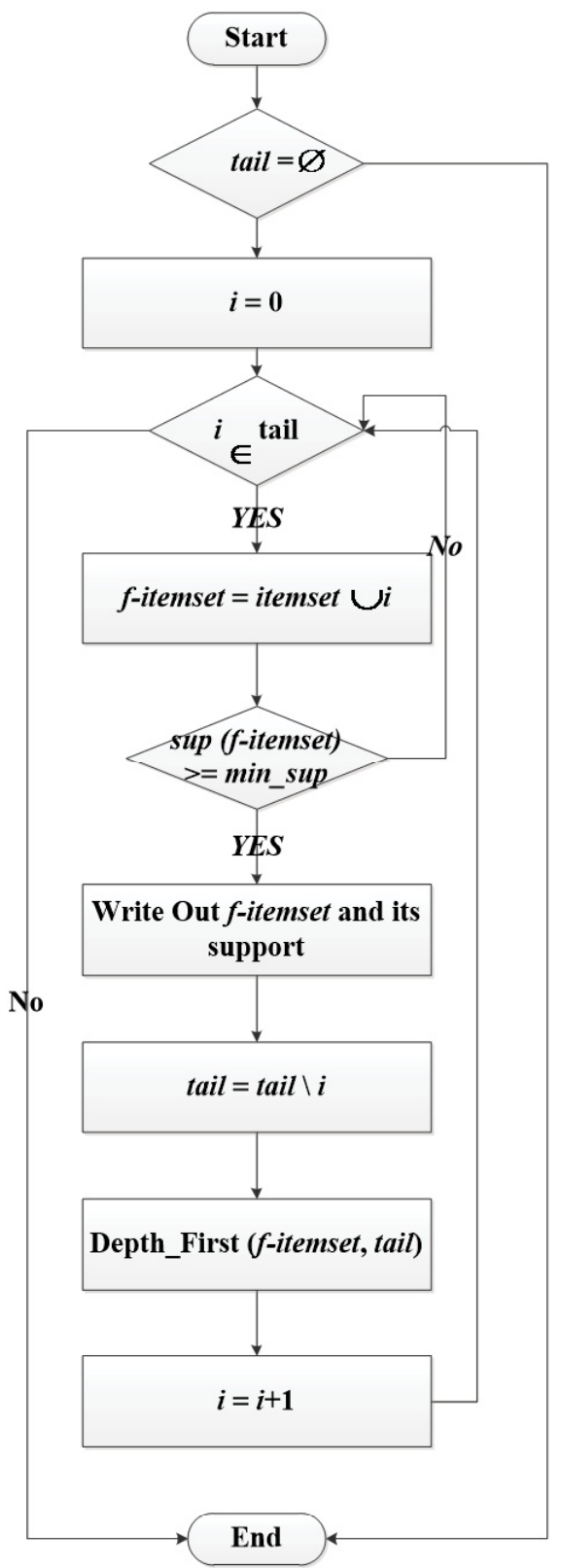

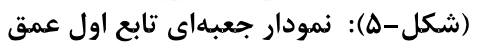

(Figure-5): Flowchart for first depth function

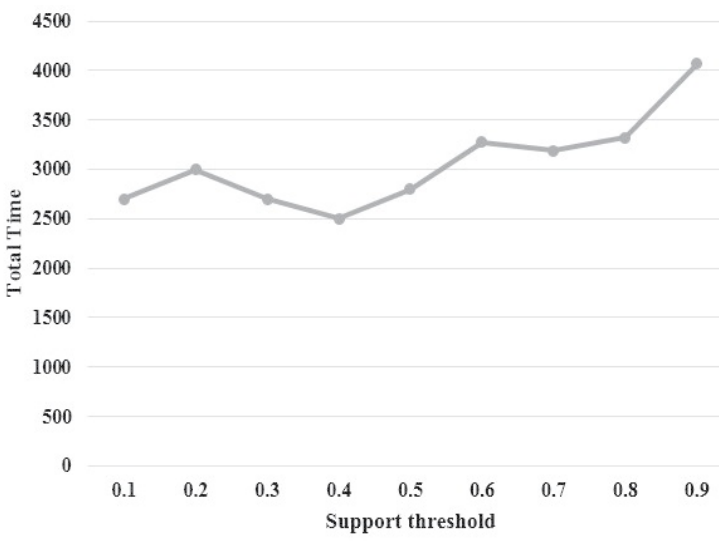

(شكل-9): زمان كل در برابر تغييرات حدآستانهُ يوشش (Figure-6): Total time vs. changes of support threshold 


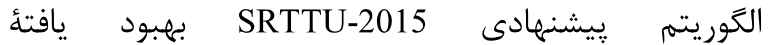
الكوريتمهاى1KD2011 و KD2013 است. درئم الكوريتم SRTTU-2015، روش يافتن : رسوجوهاى يرتكرار بهبود

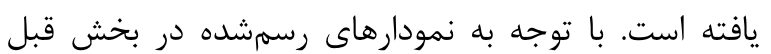

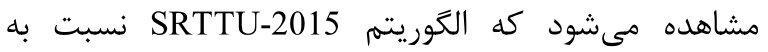
الكوريتم KD2011 از نظر معيارهاى زمانى (معيارهاى شماره (Y) و (Y))، بهطور متوسط ها I درصد بهبود و از نظر معيار شماره (1)، بلهور متوسط •له درصد بهبود داشته است.

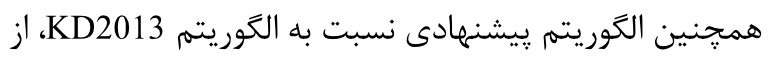

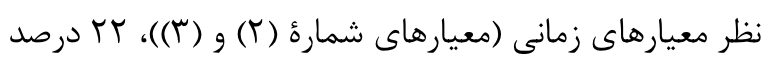

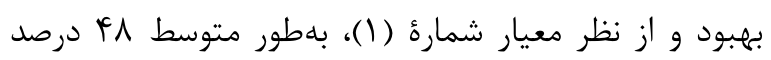
بهبود داشته است. علت اين بهبود، استفاده از الكوريتم IndexBittableFI

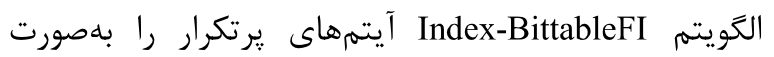
منسابترى نسبت به الكوريتمهاى Apriori و DIC ييدا

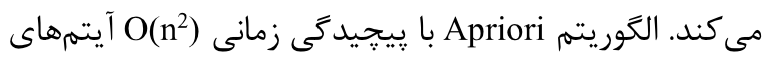

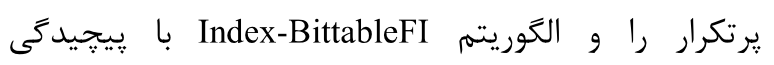
O(nlogn) الكوريتم پيشنهادى از Index-BittableFI استفاده شده است،

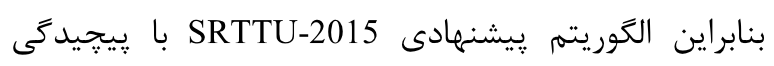
كمترى، ديدهاى مناسب را انتخاب مى كند بند

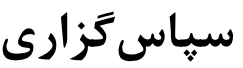

اين يزوهش با حمايت مالى دانشعاه تربيت دبير شهيد رجايى

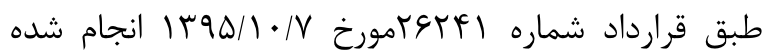

\section{6-Refrences}

[1] J. Widom, "Research Problems in Data Warehousing," in International Conference on Information and Knowledge, Baltimore, Maryland, 1995.

[2] T. V. Kumar and K. Devi, "Frequent Queries Identification for Constructing Materialized Views," in Electronics Computer Technology (ICECT), Kanyakumari, 2011.

[3] T. V. V. Kumar, G. Dubey and A. singh, "Frequent Queries Selection for View Materialization," Advances in Computing and Information Technology, vol. 177, pp. 521-530, 2013.

[4] W. Song, B. Yang and Z. Xu, "IndexBitTableFI: An improved algorithm for mining
شكل (9) نشاندهنده زمان للزم براى پياسخ به

يرسوجوهاى آزمايش در برابر تعداد يرسوجوها است. در اين نمودار محور افقى نشاندهنده تعداد يرسوجوها است و محور عمودى نشاندهنده زمان صرفشد براى ياسخ به يرسوجوهاى آزمايش است.

KD2011 $=$ KD2013 - -SRTTU-2015

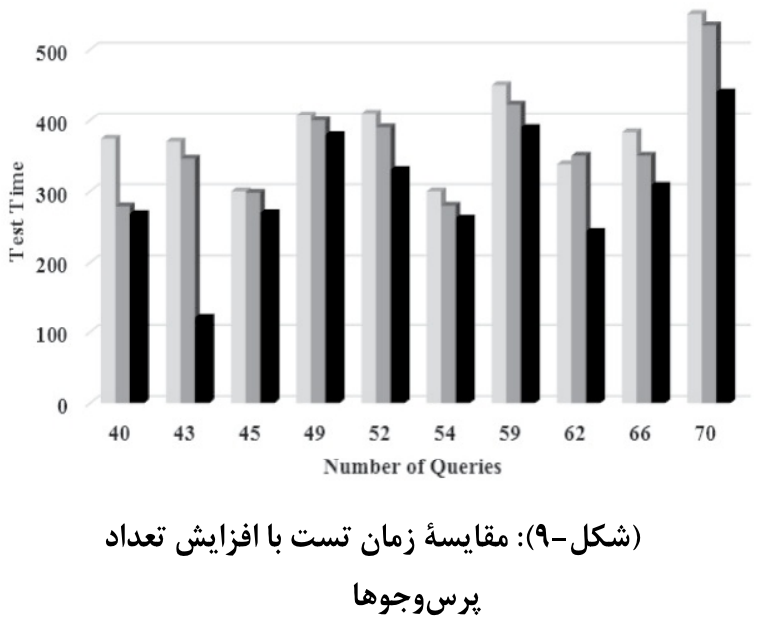

(Figure-9): Test time vs. number of queris

با توجه به نمودار رسمشده در شكل (9) مشاهده مىشود كه زمان للزم براى پاسخدادن به ״رسوجوهاى آزمايش، در الكوريتم ييشنهادى SRTTU-2015 نسبت به به يه الكوريتمهاى KD2011 و KD2013، كمتر است. الگوريتمى كه در زمان كمترى به يرسوجوهاى تست پاسخ دهد الكوريتم مناسبترى است.

با توجه به نمودارهاى رسمشده مشاهده مىشود كه

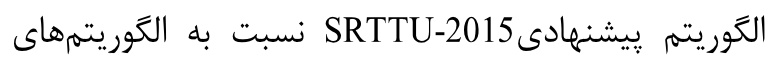
KD2011

\section{ه-نتيجه گيرى}

در اين مقاله، الكوريتمى براى انتخاب ديد ارائه شده است

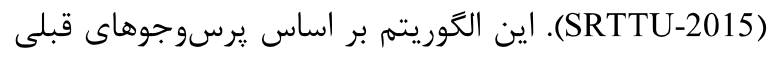

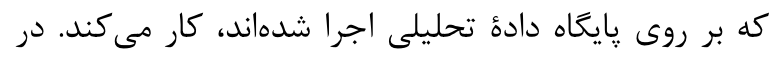

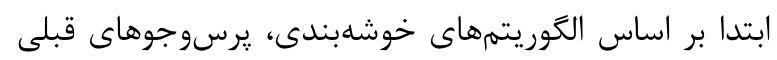
خوشهبندى مىشوند؛ سيس در هر خوشه، يرسوجوهاى

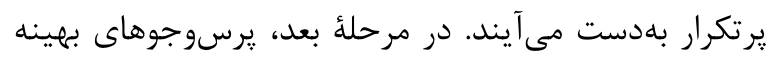

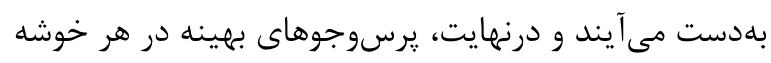
ادغام مىشوند تا بهازاى هر خوشه، يك ديد برنيد بهدست آيد. 
Extending database technology: Advances in database technology, France, 2008.

[17] T. V. Kumar and M. Haider, "Query answeringbased view selection," International Journal of Business Information Systems, vol. 18, no. 3, pp. 338-353, 2015.

[18] V. T. Kumar and M. Haider, "Selection of views for materialization using size and query frequency," Information Technology and Mobile Communication, pp. 150-155, 2011.

[19] V. T. Kumar and M. Haider, "Materialized views selection for answering queries," Data Engineering and Management, pp. 44-51, 2012.

[20] M. S. Chaudhari and D. Chandrashekhar, "Dynamic materialized view selection algorithm: a clustering approach," Data Engineering and Management, pp. 57-66, 2012.

[21] V. T. Kumar and B. Arun, "Materialized View Selection Using HBMO," International Journal of System Assurance Engineering and Management, pp. 1-14, 2015.

[22] P. Vishwanath and R. Sridhar, "An Association Rule Mining for Materialized View Selection and View Maintenance," International Journal of Computer Applications, vol. 105, no. 5, 2015.

[23] D. Yao, A. abulizi and R. Hou, "An improved algorithm of materialized view selection within the confinement of space," 2015.

[24] T. V. Kumar and K. Devi, "Materialised view construction in data warehouse for decision making," International Journal of Business Information Systems, vol. 11, no. 4, pp. 379-396, 2012.

[25] T. V. V. Kumar, A. Singh and G. Dubey, "Mining Queries for Constructing Materialized Views in a Data Warehouse," Advances in Computer Science, Engineering \& Applications, pp. 149-159, 2012.

[26] T. V. V. Kumar, A. Goel and N. Jain, "Mining information for constructing materialised views," Int. J. Information and Communication Technology, vol. 2, no. 4, pp. 386-405, 2010.

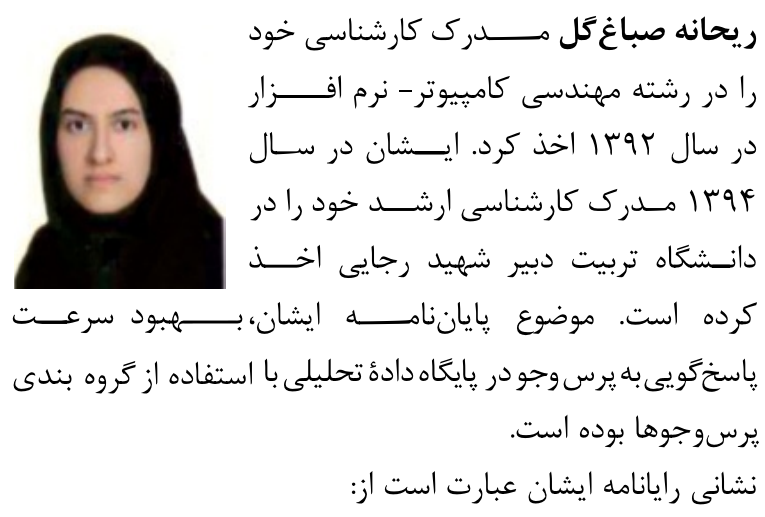

Sabbgh.rsg@gmail.com frequent itemsets," Knowledge-Based Systems, vol. 21, pp. 507-513, 2008.

[5] J. Yang, K. Karlapalem and Q. Li, "Algorithms for materialized view design in data warehousing environment," $V L D B$, vol. 97, 1997.

[6] I. Mami and Z. Bellahsene, "A survey of view selection methods," ACM SIGMOD, vol. 41, no. 1, pp. 20-29, 2012.

[7] C. A. Dhote and M. S. Ali, "Materialized view selection in data warehousing: a survey," Journal of Applied sciences, vol. 9, no. 3, pp. 401-414, 2009.

[8] J.-S. Sohn, J.-H. Yang and I.-J. Chung, "Improved view selection algorithm in data warehouse," IT Convergence and Security, pp. 921-928, 2013.

[9] A. B. Rashid, M. Islam and A. L. Hoque, "Dynamic Materialized View Selection Approach for Improving Query Performance," Computer Networks and Information Technologies, vol. 142, pp. 202-211, 2011.

[10] W. Xu, D. Theodoratos, C. Zuzarte, X. Wu and V. Oria, "A dynamic view materialization scheme for sequences of query and update statements," Data Warehousing and Knowledge Discovery, pp. 55-56, 2007.

[11] N. Daneshpour and A. Abdollahzadeh Barfourosh, "Dynamic view Management System for Query Prediction to view materialization," International Journal of Data Warehousing and Mining, vol. 7, no. 2, pp. 6796, 2011.

[12] I. Mami, R. Coletta and Z. Bellahsene, "Modeling view selection as a constraint satisfaction problem," in International Conference on Database and Expert Systems Applications, France, 2011.

[13] I. Mami, Z. Bellahsene and R. Coletta, "View selection under multiple resource constraints in a distributed context," in International Conference on Database and Expert Systems Applications, Vienne, 2012.

[14] I. Mami, Z. Bellahsene and R. Coletta, "A Declarative Approach to View Selection Modeling," Transactions on Large-Scale Dataand Knowledge-Centered Systems, pp. 115-145, 2013.

[15] R. Huang, R. Chirkova and Y. Fathi, "Advances in Databases and Information Systems," in Deterministic view selection for data analysis queries: Properties and algorithms, Berlin, Springer Berlin Heidelberg, 2012, pp. 195-208.

[16] Z. Asgharzadeh, R. Chirkova and Y. Fathi, "Exact and inexact methods for selecting views and indexes for olap performance improvement," in international conference on 


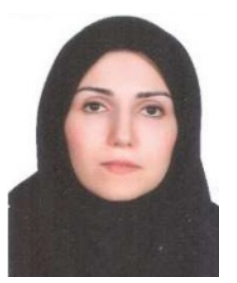

نغين دانشيور استاديار دانشكده مهندسى كامييوتر دانشكاه تربيت دبير شهيد رجايى است. نامبرده تحصيلات

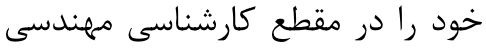

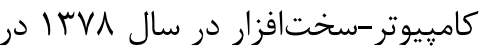
دانشكاه شهيد بهشتى و كارشناسى ارشد مهندسى كامييوتر -

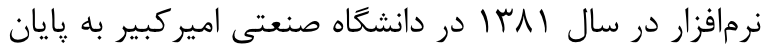

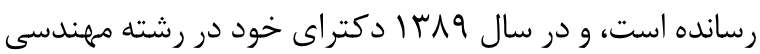
كامِيوتر-نرمافزار را از دانشكاه صنعتى اميركبير اخذ كرده است. زمينههاى يزوهشى مورد علاقه ايشان عبارتند از: باييًاه داده، بايحاه داده تحليلى، سامانههاى تصميميار، و داده كاوى.

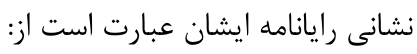
ndaneshpour@srttu.edu 